\title{
Penanaman Nilai Multikultural dengan Metode Hybrid Learning pada Masa Pandemi Covid-19
}

\author{
Cultivating Multicultural Values with the Hybrid Learning Method during the Covid-19 \\ Pandemic
}

\author{
Mia Manda Aulia ${ }^{1}$, Didik Tri Setiyoko², Diah Sunarsih ${ }^{3}$,Agus Purnomo ${ }^{4}$ \\ 1, 2,3,4 Program Studi Pendidikan Guru Sekolah Dasar, Fakultas Keguruan Dan Ilmu Pendidikan, \\ Universitas Muhadi Setiabudi Brebes, Indonesia \\ Email: ${ }^{1}$ miamandaaulia26@gmail.com, ${ }^{2}$ trisetiyokoumus@gmail.com, ${ }^{3}$ diah.sunarsih@umus.ac.id, \\ 4agus.purnomo@umus.ac.id
}

\begin{abstract}
Abstrak
Malahayu merupakan desa terluas yang ada di Kecamatan Banjarharjo, sehingga bisa dibilang memiliki jumlah penduduk terbesar dibandingkan dengan desa lain yang ada di Kabupaten Banjarharjo. Karena ada banyak orang juga ada kebiasaan yang berbeda. Dari perbedaan tersebut, jika masyarakat tidak memahami bagaimana cara menanamkan nilai-nilai multikulturalisme maka akan timbul / timbul konflik. Permasalahan di Desa Malahayu sendiri adalah kurangnya solidaritas masyarakat sesuai dengan nilai-nilai multikultural di sekitar lingkungannya. Solidaritas sosial masyarakat multikultural yang dimaksud dalam tulisan ini adalah membangun kembali solidaritas sosial yang terpecah akibat pandemi Covid-19 dan dari hasil observasi yang dilakukan menghasilkan informasi bahwa dalam setiap kegiatan pemilihan kepala desa merupakan hasil dari perbedaan Pendapat yang terjadi dalam masyarakat yang mengakibatkan perpecahan antar individu atau kelompok, sehingga solidaritas antar komunitas semakin menurun. Oleh karena itu, kegiatan pengabdian kepada masyarakat dilakukan untuk menanamkan nilai-nilai multikulturalisme pada masyarakat agar nantinya dapat diterapkan dalam kehidupan bermasyarakat agar tidak menimbulkan kerenggangan antar anggota masyarakat dan seringkali menimbulkan konflik / perpecahan antar anggota masyarakat. Kegiatan pengabdian kepada masyarakat ini dilakukan dengan menggunakan metode Hybrid Learning yang merupakan gabungan antara metode pembelajaran berbasis e-learning (pembelajaran elektronik) dengan metode pembelajaran tatap muka atau metode konvensional. Cara ini sangat tepat dilakukan pada saat pandemi Covid-19 seperti saat ini, karena bisa dilakukan secara tatap muka maupun online (media internet).
\end{abstract}

Kata kunci: Nilai Multikultural, Metode Hybrid Learning

\begin{abstract}
Malahayu is the largest village in the Banjarharjo sub-district, so you can say that it has the largest population compared to other villages in Banjarharjo District. Because there are many people there are also different habits. From this difference, if the community does not understand how to instill the values of multiculturalism, conflict will arise / arise. The problem in Malahayu village it self is the lack of community solidarity according to the multicultural values around its environment. The social solidarity of the multicultural community referred to in this paper is to rebuild social solidarity that was fractured due to the Covid-19 pandemic and from the results of observations made to produce information that in every village head election activity is a result of differences of opinion that occur in society which results in divisions between individuals or groups, so that the solidarity between communities is decreasing. Therefore, community service activities are carried out to instill the values of multiculturalism in the community so that later they can be applied in living in the community so that they do not cause estrangement between community members and often lead to conflict / division between community members. This community service activity is carried out using the Hybrid Learning method, which is a combination of e-learning-based learning (electronic learning) methods with face-to-face learning methods or conventional methods. This method is very appropriate to do during the Covid-19 pandemic like today, because it can be done face-to-face or online (internet media).
\end{abstract}

Keywords: Multicultural Value, Hybrid Learning Method

Submitted: Januari 2021, Accepted: Februari 2021, Published: Februari 2021

ISSN 2746-6345 (media online) 


\section{PENDAHULUAN}

Karakter dan perkembangan diri manusia dibentuk melalui salah satu unsur yaitu pendidikan. Pendidikan seakan tidak ada hentinya menjalankan peran penting untuk menjadikan manusia atau peserta didik memahami nilai nilai dalam kehidupan bermasyarakat.

Pentingnya pendidikan perlu ditingkatkan dalam kesadaran Masyarakat, mengingat peristiwa sejarah pada masa perang dunia dua. Jepang kala itu di bom oleh sekutu, kota Hiroshima dan Nagasaki di bom atom oleh sekutu dan luluh lantah. Lalu apa yang direspon kaisar jepang pada saat itu, kaisar menanyakan kepada para pejabat kekaisaran "berapa jumlah guru yang tersisa dari peristiwa pengebobam tersebut?". Kaisar jepang menyadari bahwa pendidikan adalah unsur yang penting dalam membangun sebuah bangsa. Maka dari itu jepang mampu bangkit dari keterpurakan pada masa perang dunia dua dan menjadi sebuah negara yang maju dan disegani didunia. Membangun disini tentu tidak diartikan membangun secara fisik saja tetapi juga membangun jiwa masyarakat itu lebih penting. Jiwa yang rapuh membuat manusia tidak menjadi manusia yang merdeka.

Malahayu adalah desa yang terluas di kecamatan Banjarharjo, untuk itu bisa dibilang masyarakatnya paling banyak dibanding desa-desa lain di Kecamatan Banjarharjo. Karena banyaknya masyarakat banyak juga kebiasaan yang berbeda-beda. Dari perbedaan itu jika masyarakat tidak mengerti cara menanamkan nilai-nilai multikulturalisme maka akan muncul / timbul konflik. Permasalahan yang ada di desa Malahayu sendiri kurangnya solidaritas masyarakat sesuai nilai-nilai multikultural di sekitar lingkungannya. Jika masing-masing individu menyadari peranan yang dimiliki dan dijalankan sesuai porsi maka sikap emosional dalam diri individu akan sedikit demi sedikit menghilang.

Konflik merupakan hal yang merugikan atau merusak jika konflik tersebut tidak bisa diatasi dengan arif dan bijak. Didalam kehidupan masyarakat yang majemuk dan penuh dengan perbedaan maka konflik tidak dapat dihindari. Tetapi konflik sebenarnya dapat dimanajemen untuk menjadikan konflik bernilai positif. Artinya membalikan nilai konflik dari negatif ke positif tentulah tidak mudah. Memainkan pemikiran publik dibutuhkan energi yang luar biasa. Untuk itu dibutuhkan banyak perananan dari berbagai struktur yang ada dalam masyarakat tersebut. Pendidikan adalah salah satu unsur yang sangat penting dalam membentuk karakter manusia. Maka dari itu pendidikan multikultural dibutuhkan pada masyarakat yang majemuk, memiliki khasanah kebudayaan yang berbeda-beda. Perbedaan bukanlah suatu halangan untuk mewujudkan harmony dalam kehidupan berbangsa dan bernegara. Justru perbedaan itu bisa menjadikan kekuatan yang dasyat untuk kehidupan masyarakat yang adil, damai, dan sejahtera.

Solidaritas sosial masyarakat multikultural yang dimaksud dalam tulisan ini adalah membangun kembali solidaritas sosial yang retak akibat pandemi Covid-19. Ide ini berupaya agar memiliki dua tujuan yaitu selain memutus mata rantai penyebaran Covid-19 juga mempertahankan solidaritas sosial pada masyarakat multikultural yang memerlukan kesadaran dari pemerintah baik dalam bidang kesehatan, keamanan dan masyarakat. Karena Desa malahayu dikatakan desa terluas yang memiliki 13 dusun atau dukuh yakni Dusun Limbangan, dusun Kanari, dusun Maibah, Blok 1, Blok 2, Blok 3, Blok 4, Dusun Kalimati, Dukuh Cawiri, Dukuh Balsiah, Dukuh Anjun, Dukuh Pari, dan Kracak atau 13 RW dan 33 RT. Desa Malahayu mempunyai beberapa tempat peribadatan bagi umat muslim kegiatan keagamaan yang rutin dilakukan oleh masyarakat desa Malahayu adalah sholat berjamaah setiap hari dan setiap hari jum'at kelompok pemuda hingga masyarakat mengadakan yasinan di mushola maupun masjid terdekat Disetiap pemilihian kepala desa terdapat perbedaan pendapat yang terjadi di masyarakat yang mengakibatkan perpecahan antar individu atau golongan, sehingga solidaritas antar masyarakatpun semakin berkurang. Hal tersebut menyebabkan kerenggangan antar warga masyarakat dan seringkali menimbulkan konflik/perpecahan antar warga masyarakat akibat masalah sepele yang sebenarnya semua itu adalah hak dan kewajiban masing-masing individu dalam berpolitik. Dengan adanya hal tersebut saya ingin memberikan pemahaman untuk masyarakat desa Malahayu agar dapat menanamkan nilai-nilai multikultural menggunakan metode Hybrid Learning dalam kehidupan sehari-sehari di masyarakat. 
Hasil penelitian M. Ubaidillah (2020) yang mengkaji tiga permasalahan yaitu proses penanaman nilai-nilai multikultural, faktor pendukung dan penghambat dan hasil penanaman nilai-nilai multikultural, Hasil dari penelitian penanaman nilai-nilai multikultural melalui PAI yaitu, Proses penanaman nilai-nilai multikultural di SMK Ketintang Surabaya, menggunakan model pengajaran aktif dan komunikatif dengan metode diskusi dan tanya jawab.

Selanjutnya adalah hasil penelitian Fita Mustafida (2020) yang mengkaji tentang Integrasi Nilai-nilai Multikultural dalam Pembelajaran Pendidikan Agama Islam (PAI) yang menghasilkan kesimpulan bahwa strategi yang dapat dilakukan dalam mengintegrasikan nilai multikultural yakni dengan cara pengenalan, pemahaman, dan penghargaan terhadap keberagaman, menghindari pandangan-pandangan yang menganggap lebih unggul kelompok tertentu, menumbuhkan dan membiasakan sikap dialogis.

Implementasi penanaman nilai-nilai multikultural dalam pendidikan agama Islam yang dilakuakn melalui integrasi dalam proses pembelajaran baik formal maupun non formal. Contohnya adalah integrasi nilai dalam materi, metode dan media pembelajaran yang berprinsip dan beroreintasi pada nilai-nilai multikultural. Secara sederhana pendidikan multiltural, dapat disimpulkan sebagai pendidikan untuk / tentang keragaman kebudayaan dalam merespon perubahan demografis dan kultural lingkungan masyarakattertentu atau bahkan dunia secara keseluruhan, yang bertujuan untuk menciptakan kehidupan yang harmonis dalam masyarakat yang serba majemuk. Hal ini sesuai dengan tujuan dari pendidikan islam itu sendiri, diperkuat dengan banyak ayat-ayat al-Qur'an yang menjelaskan tentang multikulturalisme serta nilai-nilai yang terdapat di dalamnya, seperti toleransi, tolong menolong, saling menghormati, keadilan, demokratis dan sejenisnya.

Perbedaan artikel ini dengan penelitian-penelitian sebelumnya adalah sasaran dan metode yang digunakan dalam kegiatan tersebut. Artikel ini hasil observasi di masyarakat desa Malahayu mengenai nilai-nilai multikultural dalam kehidupan dimasyarakatnya sehari-hari dengan sasaran utamanya adalah pemuda pemudi desa Malahayu dan kegiatan pengabdian kepada masyarakat ini dilakukan dengan metode Hybrid Learning. Jadi dengan adanya kegiatan pengabdian kepada masyarakat ini untuk memberikan pengetahuan kepada pemuda pemudi tentang nilai-nilai multikultural yang harus dipahami dan ditanamkan dalam diri masing-masing individu.

Maksud program pengabdian masyarakat ini bagi pemuda pemudi Desa Malahayu yaitu agar warga masyarakat dapat menerima segala perbedaan, dapat menghargai pendapat orang lain yang tidak sesuai dengan pemikiran atau sudut pandang kita. Serta memberikan pemahaman kepada peserta pengabdian masyarakat bahwa setiap budaya dan setiap etnis sama nilai antar satu dengan yang lain. Sehingga kepercayaan diri dimiliki dalam melakukan pola interaksi dan komunikasi dengan individu atau orang lain (kelompok etnis) walau memiliki perbedaan budaya dalam masyarakat dan memiliki nilai kearifan lokalnya masing-masing. Klarifikasi nilai dan sikap, Pendidikan memiliki peran mengangkat nilai inti yang berasal dari martabat manusiai itu sendiri yaitu keadilan, persamaan, dan demokratis. Sehingga pendidikan multikultural sangat membantu pemuda pemudi di tempat pengabdian masyarakat dalam memahami berbagai konflik yang tidak dapat dihindari dalam kehidupan bermasyarakat.

Agar menciptakan persamaan peluang pendidikan bagi semua peserta didik yang berbeda ras, etnis, kelas sosial, dan kelompok budaya. Diharapkan supaya warga masyarakat desa Malahayu dapat mengahargai adanya perbedaan pendapat antar masing-masing individu karena hak dan kewajiban masing-masing individu pun berbeda. Jika hal tersebut ditanamkan dengan baik oleh warga masyarakat maka masyarakatnya akan rukun dan damai.

\section{METODE PELAKSANAAN}

Sasaran dari kegiatan ini adalah masyarakat khususnya pemuda pemudi desa Malahayu, karena mereka calon generasi penerus agar mampu memahami serta menanamkan nilai multikultural. Tujuan dari pelaksanaan kegiatan ini adalah untuk memberikan pemahaman serta 
menanamkan nilai-nilai multikultural. Membiasakan masyarakat hidup dengan menerapkan nilai-nilai multikultural sehingga

Kegiatan pengabdian masyarakat ini diawali dengan proses observasi yang bertujuan untuk mengetahui permasalahan yang ada di desa Malahayu. Observasi ini dilakukan dengan cara wawancara warga masyarakat desa Malahayu, kemudian dilanjut dengan perencanaan kegiatan. dilakukan sebanyak 2 kali pertemuan dengan beberapa langkah yakni pemaparan materi tentang nilai-nilai multikultural, serta mengaktualisasi diri masing-masing individu. Kegiatan ini tentunya memerlukan partisipasi mitra seperti, desa sebagai penyedia fasilitas berupa tempat (aula balaidesa Malahayu) untuk pelaksanaan pembelajaran serta pelatihan penerapan nilai-nilai multikultural dalam kehidupan bermasyarakat. Serta warga masyarakat desa Malahayu yang ikut berperan serta dalam kegiatan pengabdian kepada masyarakat ini

Proses pelaksanaan kegiatan ini dilakukan sebanyak 2 kali pertemuan dalam kurun waktu 2 hari. Hari pertama adalah kegiatan yang diawalai dengan pemahaman tentang pendidikan nilai-nilai multikultural, dengan tujuan antara lain agar masyarakat memahami tentang pendidikan nilai-nilai multikultural, agar masyarakat memahami pentingnya pendidikan multikultural dalam kehidupan bermasyarakat, agar masyarakat memahami peranan masingmasing individu dalam kehidupan bermasyarakat

Kegiatan dihari kedua adalah pelatihan dan penanaman nilai-nilai multikultural didesa Malahayu yang bertempat di Blok 3. Dikegiatan ini dilakukan penanaman nilai-nilai multikultural dalam diri masing-masing individu, diantaranya untuk menciptakan dan terwujudnya pesamaan peluang pendidikan bagi semua peserta didik yang berbeda-beda etnis dan kelompok budaya, klarifikasi nilai dan sikap. Pendidikan berperan mengangkat nilai-nilai inti yang berasal dari prinsip martabat manusia (ciptaan Tuhan YME), keadilan, persamaan, dan, dan demokratis. Sehingga pendidikan multikultural membantu peserta didik memahami bahwa berbagai konflik nilai tidak dapat dihindari dalam lingkungan masyarakat yang pluralistik, memperkuat pribadi sihingga muncul adanya reformasi sosial. Peserta didik difasilitasi konsep pendidikan multikultural agar memiliki dan mampu mengembangkan sikap, nilai, kebiasaan, dan keterampilan sehingga dapat menjadii agen perubahan social hingga pepimpin perubahn sosial yang memiliki komitmen tinggi (integritas) dalam reformasi masyarakat untuk memanajemen konflik perbedaan etnis dan rasial

Metode yang digunakan dalam pengabdian masyarakat ini adalah Hybrid Learning yang berarti pembelajaran kombinasi antara tatap muka, pembelajaran berbasis komputer (offline), dan pembelajaran berbasis internet (online). Artinya pembelajaran dengan pendekatan teknologi pembelajaran dengan kombinasi sumber-sumber belajar tatap muka dengan pengajar maupun yang dimuat dalam media komputer, telpon seluler, konferensi video, saluran televisi, serta media berkelanjutan.

Blended learning dikembangkan memiliki tujuan menggabungkan kekhasan dalam pembelajaran yang terbaik dari pembelajaran di ruang pembelajaran (tatap muka) dan kekhasan pembelajaran terbaik sistem online untuk meningkatnya pembelajaran merdeka secara aktif oleh peserta didik dan mengurangi jumlah waktu tatap muka di kelas. Fokus Blended Learning adalah mengubah bentuk pembelajaran klasik agar dapat menghasilkan peserta didik lebih aktif mempelajari materi pembelajaran di dalam dan di luar kelas. Keatfifan peserta didik tentu dapat memberikan dampak yang positif. Akhir tujuan Blended Learning adalah meningkatkan pemahaman peserta didik mengenai materi pembelajaran yang ditunjukkan dengan meningkatnya nilai mata pelajaran.

Pembelajaran ini bertujuan menghasilkan peserta didik yang aktif. Membuat peserta didik memiliki kemerdekaan dalam berpikir, sehingga membuat orang yang berwawasan luas dan terbuka (open mind). Tidak ada batasan dalam mencari sumber maupun literasi yang komprehensif. Semakin banyak sumber dan literasi yang di dapatkan, maka kevalidan kesimpulan yang ditarik juga akan semakin terpercaya. Hal seperti ini sangatlah tepat dalam mengembangkan daya nalar peserta didik dalam menganalisis problematika sosial yang sedang terjadi ditengah lingkungan masyarakat yang multikultur. 
Adapun pengertian Hybrid Learning lainnya yaitu gabungan dari beberapa metode yang berkenaan dengan cara siswa mengadopsi konsep. Pembelajaran Hybrid Learning merupakan pembelajaran yang bersifat metodologi yang menggabungkan beberapa metode pembelajaran yaitu Traditional classes (TC) adalah pembelajaran dilakukan secara tradisional/ekspositori, Real workshop (RW) adalah pembelajaran dengan komputer sebagai alat bantu, Virtual workshop (VW) adalah pembelajaran dengan internet.

Pembelajaran Hybrid Learning bertujuan mengaktifkan pikiran peserta didik dengan menghindari kedunguan berpikir dan menghindarkan dari ketidak logisan dalam menganalisis peristiwa secara holistik. Ini bisa dilakukan secara integrasi yaitu Traditional Classes-Real Workshop-Virtual Workshop (TC-RW-VW)

Dengan adanya kegiatan pengabdian masyarakat ini masyarakat lebih memahami bahwa perbedaan tidak harus dihadapai dengan perlawanan. Dari hal tersebut masyarakat lebih menghargai disetiap perbedaan baik dalam hal, perbedaan pendapat, kebiasaan, serta hal lainnya dalam kehidupan bermasyarakat. Dalam penanaman nilai-nilai multikultural tersebut melalui pendidikan multikultural guru tentunya berusaha mengomunikasikan cara hidup menghormati, tulus, dan toleran terhadap keberagaman yang ada dimasyarakat. Indikator keberhasilan pengabdian kepada masyarakat ini dapat dilihat setelah kegiatan pelatihan penanaman nilai-nilai multikultural. Masyarakat mulai dapat menerapkan aspek-aspek sosial yang ada dalam kehidupan bermasyarakat, mulai menghargai segala perbedaan yang ada yalam hubungan sosial masyarakat. Sehingga kerukuran dan ketentraman selalu terjaga dalam berkehidupan di masyarakat.

\section{HASIL DAN PEMBAHASAN}

Kegiatan pengabdian kepada masyarakat dengan tema Penanaman Nilai Multikultural dengan Metode Hybrid Learning Pada Masa Pandemi di Desa Malahayu dilakukan pada awal sampai akhir bulan September 2020. Penanaman nilai-nilai multikultural disampaikan dengan cara yang menarik, sesuai dengan dunia mereka. Dan dapat diterima oleh generasi millenial yang penuh dengan tantangan dan perubahan jaman yang begitu cepat Kegiatan ini tidak lepas dari proses perencanaan, pelaksanaan, dan evaluasi. Terkait dengan perencanaan dalam pengabdian kepada masyarakat ini harus diawali dengan observasi permasalahan yang ada di Desa Malahayu khususnya mengenai nilai-nilai multikultural pada kehidupan masyarakatnya. Dan dihasilkan bahwa masyarakat desa Malahayu khususnya pemuda pemudi sering terjadi kesalah pahaman antara individu satu dengan individu lainnya atau bahkan antar golongan. Pada tanggal 19 September 2020 pukul 13.00 sampai dengan selesai dilakukan sosialisasi penanaman nilai-nilai multikultural pada masyarakat dengan menerapkan protokol kesehatan sesuai anjuran pemeraintah yakni audien diwajibkan memakai masker dan dari penyelenggara kegiatan pun menyediakan handsanitizer. Di kegiatan sosialisasi ini ada berbagai rangkaian kegiatan yaitu, pemaparan materi tentang nilai-nilai multikultural dan dilanjut dengan sesi tanya jawab oleh masyarakat yang mengikuti kegiatan sosialisasi. Dari pertanyaan-pertanyaan tersebut untuk kemudian di jawab atau didiskusikan bersama oleh narasumber dan audien. Dihari berikutnya yaitu kegiatan tentang Pelatihan Penanaman nilai-nilai multikultural dengan metode Hybrid Learning.

Hybrid Learning atau yang juga dikenal dengan istilah Blended Learning merujuk kepada pengkombinasian metode. Penggabungan dua metode pembelajaran yang saling melengkapi dengan tujuan memaksimalkan hasil dari pembelajaran tersebut, yaitu metode tradisonal dan metode on line. Model blended learning memiliki kelebihan antara lain peserta didik leluasa untuk mempelajari materi pelajaran secara mandiri dengan memanfaatkan materi-materi yang tersedia secara online atau daring, peserta didik juga dapat melakukan diskusi yang menarik dengan guru atau dengan peserta didik lain diluar jam tatap muka, kegiatan pembelajaran diluar jam tatap muka bisa dikontrol dan dikelola dengan baik oleh guru melalui sebuah aplikasi digital, guru bisa membuat materi yang disenangi pesrta didik sehingga tidak terasa 
membosankan. Peserta didik juga dapat berbagi pengetahuan dengan peserta didik yang lain sehingga terjadi pola komunikasi yang satu arah atau pola komunikasi yang cenderung monoton. Hal ini menjadikan tercapainya tujuan pembelajaran dengan baik atau sering kita sebut outcome peserta didik telah tercapai dengan maksimal. Sedangkan kelamahan blended learning yaitu media yang dibutuhkan sangat beragam (kompleks), sehingga sulit diterapkan apabila sarana dan prasarana tidak mendukung atau kurang memadai, pemerataan fasilitas jaringan komunikasi dan informasi tidak terjadi disetiap daerah. Ada daerah yang memiliki fasilitas lengkap dan memadai, ada daerah yang bahkan untuk mencari sinyal operator saja susah sekali. Kondisi seperti ini terkadang dialami baik guru maupun peserta didik yang menjalankan pembelajaran daring. Ditambah dengan kurangnya peran dan dukungan orang tua peserta didik dalam proses pembejaran blended ini. Tahapan yang terakhir adalah evaluasi diamana pengabdian kepada masyarakat ini dilakukan sesuai dengan kebutuhan masyarakat, sehingga masyarakat lebih bersikap rukun antar individu satu dengan individu lainnya. Kegiatan pengabdian kepada masyarakat ini bertujuan untuk menanmkan nilai-nilai multikultural, nasionalisme, kebhinekaan, dan rasa cinta tanah air. Sehingga eksistensi bangsa ini dapat terjaga dengan baik dari segala ancaman yang akan menghadang.

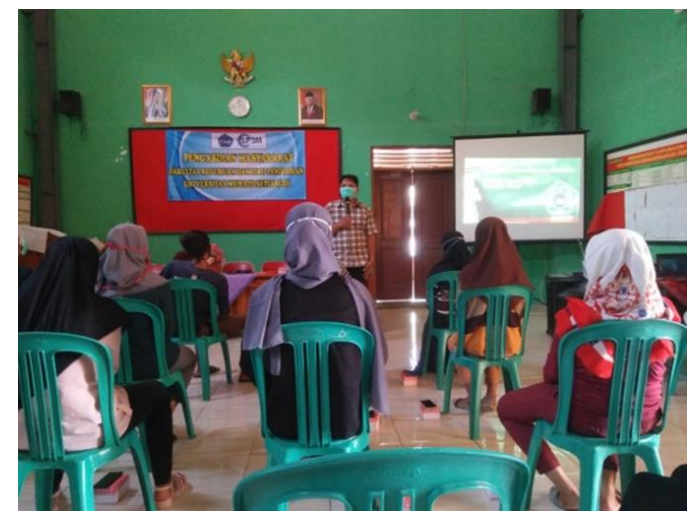

Gambar 1. Kegiatan Sosialisasi Penanaman Nilai Multikultural

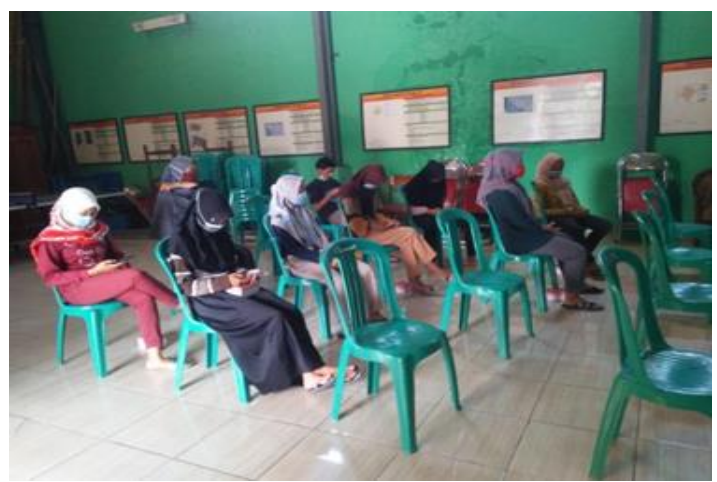

Gambar 2. Pelatihan Penanaman Nilai Multikultural

Yang dihasilkan dari kegiatan tersebut iyalah bahwa sebenarnya masyarakat sudah mengetahui tentang peranan nilai-nilai multikultural, akan tetapi rendahnya kesadaran antar masyarakat membuat hal tersebut menjadi kurang diperhatikan. Sehingga perlu adanya strategi untuk menanamkan nilai-nilai multikultural dalam kehidupan bermasyarakat.

Di dalam dunia pendidikan saat ini, strategi adalah hal yang penting. Didalam strategi ada perencanaan yang dilakukan sebelum proses pembelajaran tersebut dilaksanakan. Perencanaan yang matang akan mengarahkan pada pemilihan metode yang tepat guna untuk tercapainya suatu tujuan pembelajaran tersebut. Dalam melakukan pemilihan diharapkan 
mempertimbangkan segala aspek yang berkaitan dengan pembelajaran. Termasuk mempertimbangkan kekurangan yang dihadapi. Kemampuan menganalisis dengan baik, menjadikan perencanaan dapat disusun secara efektif dan efisisen. Langkah-langkah yang dilakukan akan tersitematis dan terarah. Seni dalam menentukan langkah-langkah seperti ini bisa dilatih dengan kebiasaan yang dilakukan secara berulang-ulang. Sistem yang sudah terbentuk secara kokoh menjadikan usaha dalam mencapai tujuan pembelajaran dapat diwariskan. Untuk kesinambungan tujuan dari pendidikan yang lebih luas.

Keberlanjutan Program ini setelah pengabdian kepada masyarakat selesai diharapkan warga masyarakat bisa menjaga nilai-nilai multikultural selalu terimplementasikan dalam kehidupan bermasyarakat. Menjaga keharmonisan dalam kehidupan berbangsa dan bernegara. Mampu menghargai segala perbedaan yang ada. Dapat berpendapat dan mampu untuk mendengarkan pendapat orang lain adalah adalah salah satu contohnya. Menghindari konflik yang bersifat merusak, dan mampu mengubah konflik menjadi kompetisi yang sehat.

\section{Kutipan dan Acuan}

1. Maslan Abdin menjelaskan Anugerah Tuhan dapat dipastikan berpeluang positif dan negatif, sehingga hal itu perlu dikelola melalui usaha pengenalan, penghayatan dan penghargaan dengan mengembangkan dialog-dialog serta apresiasi budaya sehingga mampu mewujudkan situasi dan kondisi harmonis dalam kehidupan bermasyarakat, berbangsa, dan bernegara yang pada akhirnya untuk menghindari disintegrasi bangsa dari kerangka Negara Kesatuan Republik Indonesia (Maslan Abdin, 2020)

2. I Made Dharma Atmaja mengatakan cakupan Multikultural yaitu adanya beranekaragam budaya dalam suatu wilayah yang muncul dari berbagai kelompok masyarakat baik yang bersifat tradisional ataupun modern. dengan latar belakang ditentukan berdasarkan kelas sosial, ras, etnis, adat-istiadat, gender, dan agama. Keberagaman budaya senantiasa akan memberikan pengaruh bagi cara manusia dalam berpikir, bersikap, dan bertingkah laku. Pendidikan multikultural dapat dijadikan sebagai sarana dalam pengembangan wawasan, pengetahuan, dan melakukan pembinaan sikap toleran. Lahirnya Pendidikan multikultural yaitu dari masyarakat yang mulai sadar akan pentingnya saling menghargai perbedaan etnis, suku bangsa, bahasa, dan kultur masyarakat. Guru menjadi subjek yang berperan besar dalam melakukan penanaman nilai-nilai inti pendidikan multikultural seperti demokrasi, humanisme, dan pluralism (I Made Dharma Atmaja, 2020)

3. Dwi Kartikawati mengatakan kompetensi komunikasi yang dimiliki guru akan mampu membangun komunikasi sekaligus menanamkan pengaruh positif pada peserta didiknya dalam hal pemahaman dan pengimplementasian nilai-nilai multikultural. Hal tersebut dilakukan dengan cara mengintegrasikan ke dalam pelajaran integrasi mata pelajaran dilingkungan belajar peserta didik, memahami peserta didik yang berbeda, penggunaan metode pembelajaran khusus, pembinaan karakter, dan melatih kerjasama dalam kelompok. Seorang Guru harus memiliki Kemampuan komunikasi dalam ranah pembelajaran melalui penanaman nilai-nilai multikultural menjadi ketrampilan yang penting dan logis yang dimiliki oleh guru. Ketrampilan komunikasi dan pola interaksi pada guru sangat membantu dalam proses kegiatan pembelajaran, terkait dengan kemampuannya dalam mengkomunikasikan gagasan atau ide dan pemikirannya dalam pembelajaran multikultural dalam bentuk verbal atau non verbal (Dwi Kartikawati, 2019)

\section{KESIMPULAN}

Pengabdian kepada masyarakat dengan tema Penanaman Nilai Multikultural dengan Metode Hybrid Learning Pada Masa Pandemi di Desa Malahayu dilakukan pada awal sampai akhir bulan September 2020. Dari kegiatan ini menghasilkan bahwa masyarakat desa Malahayu khususnya pemuda pemudi sering terjadi kesalah pahaman antara individu satu dengan individu lainnya atau bahkan antar golongan. Pada tanggal 19 September 2020 pukul 13.00 sampai 
dengan selesai dilakukan sosialisasi penanaman nilai-nilai multikultural pada masyarakat dengan menerapkan protokol kesehatan sesuai anjuran pemeraintah yakni audien diwajibkan memakai masker dan dari penyelenggara kegiatan pun menyediakan handsanitizer.

Penanaman nilai-nilai multikultural dengan menggunakan metode Hybrid Learning yang dilakukan di Desa Malahayu dimasa pandemi covid-19 mungkin sangat tepat untuk dilaksanakan karena dari pengertian metode Hybrid Learning sendiri adalah pengkombinasian metode pembelajaran berbasis e-learning (electronic learning) dengan metode pembelajaran tatap muka atau metode konvensional. Metode ini sangat tepat dilakukan dimasa pandemi seperti sekarang ini, karena dapat dilakukan dengan cara daring (dalam jaringan) ataupun dengan tatap muka seperti kegiatan pada umumnya. Pembelajaran Hybrid Learning merupakan pembelajaran yang bersifat metodologi yang menggabungkan beberapa metode pembelajaran yaitu traditional classes (TC) adalah pembelajaran dilakukan secara tradisional/ekspositori, Real workshop (RW) adalah pembelajaran dengan komputer sebagai alat bantu, Virtual workshop (VW) adalah pembelajaran dengan internet. Masyarakat sebenarnya sudah mengetahui tentang peranan nilai-nilai multikultural, akan tetapi rendahnya kesadaran antar masyarakat membuat hal tersebut menjadi kurang diperhatikan. Sehingga perlu adanya strategi untuk menanamkan nilai-nilai multikultural dalam kehidupan bermasyarakat dan berbangsa. Akar kata multikulturalisme adalah kebudayaan. Secara etimologis, multikulturalisme dibentuk dari kata isme (aliran pemikiran/ideolgi/paham), kultur (budaya), dan multi (banyak).

Pembelajaran Hybrid Learning bertujuan untuk memberikan pengalaman yang paling efektif dan efisien dengan cara menggabungkan pertemuan konvensional atau tatap muka di kelas dengan pengelolaan lingkungan e-Learning secara integrasi yaitu Traditional ClassesReal Workshop-Virtual Workshop (TC-RW-VW).

Keberlanjutan Program ini setelah pengabdian kepada masyarakat selesai diharapkan warga masyarakat bisa menjaga nilai-nilai multikultural selalu terimplementasikan dalam kehidupan bermasyarakat

\section{UCAPAN TERIMAKASIH}

1. Bapak Sutari A.Md.Kep. selaku Kepala Desa Malahayu yang telah mendukung kegiatan pengabdian kepada masyarakat.

2. Peтuda pemudi desa Malahayu yang telah berkenan membantu jalannya kegiatan pengabdian kepada masyarakat

3. LP3M Universitas Muhadi Setiabudi yang telat banyak memotivasi Mahasiswa Peserta $K K N$.

4. Bapak Didik Tri Setyoko selaku Dosen Pembimbing Lapangan.

\section{DAFTAR PUSTAKA}

Abidin, Maslan. 2020. Kedudukan dan Peran Wagra Negara dalam Masyarakat Multikultural. JPC. Vol 1, No. 1 (17-25)

Agustian, Murniati. 2019. Pendidikan Multikultural. Jakarta. Universitas Katolik Indonesia Atma Jaya

Agustian, Murniati. 2019. Pendidikan Multikultural. Jakarta. Universitas Katolik Indonesia Atma Jaya

Atmaja, I Made Dharma. 2020. Membangun Toleransi Melalui Pendidikan Multikultural. Jurnal Pendidikan Kewarganegaraan Undiksha Vol. 8 No. 1 
Kartikawati, Dwi, 2019. Penanaman Nilai-Nilai Multikultural yang Dipengaruhi oleh Kompetensi Komunikasi Guru di Sekolah Dasar Inklusi Trirenggo Yogyakarta. JurnalAntropologi Isu-Isu Sosial Budaya - VOL. 22 NO. 02

Khoeroh, Ni'matul, dkk. 2017. Pengaruh Model Pembelajaran Blended Learning dan Motivasi Belajar terhadap Hasil Belajar Siswa. Jurnal Penelitian Ilmu Pendidikan Volume 10, Nomor 2

Mustafida, Fita. 2020. Integrasi Nilai-Nilai Multikultural dalam Pembelajaran Pendidikan Agama Islam (PAI). Jurnal Pendidikan Islam Indonesia Volume 4, Nomor 2, April 2020

Nurkholis. 2020. Nilai-Nilai Pendidikan Multikultural Perspektif Al Qur'an. Jurnal STAI Bimadani Vol. 3

Sari, Milya. 2019. Mengenal lebih Dekat Model Blended Learning dengan Facebook. Yogyakarta. CV Budi Utama

SodiQ, M. Anang Sholikhudin. 2018. Strategi Penanaman Nilai-Nilai Multikultural (Studi Kasus di Madrasah Tsanawiyah Darut Taqwa 02 Sengonagung Purwosari Pasuruan) Journal MULTICULTURAL of Islamic Edication Volume 2, Nomor 1

Sutiah. 2019. Pengembangan Pembelajaran Hybrid Learning. Sidoarjo. Nizamia Learning Center

Ubaidillah, M. 2020. Penanaman Nilai-Nilai Multikultural Melalui Pendidikan Agama Islam di SMK Ketintang Surabaya. Jurnal Widyaloka IKIP WIDYA DARMA Vol. 7, No. 2 